\title{
植物 病理化学の発展
}

\section{瓜 谷 郁 三 名古屋大学農学部}

植物病理化学 (Phytopathological Chemistry) とは, 植物が示す異常な生命現象を化学の言葉で説明すること を目的とする学問分野であり，その中には，その得られ た成果を植物疾病防除その他に応用する化学分野も含ま れる、したがって, 植物病理学ないし植物生理学の一領 域ともみられるし, また農芸化学にも関連している.

鈴木梅太郎(1)が, 1896 年に大学を卒業し, 大学院に入 って最初に取組んだ研究が桑の萎縮病であった. これこ そわが国の農芸化学に特いて, 植物疾病現象が研究課題 として採り上げられた最初の例である. 鈴木は当時の限 られた生化学的知識と化学的方法とをもって, 萎縮病の。 発生原因を研究し，それが生理病であろうと推定してそ の防除法を具体的に示した. 現在この病気はマイコプラ ズマ病であるとわかっているが，これが植物より初めて 証明されたのは 1967 年 (土居ら ${ }^{(2)}$ にる) であることか らして, 当時, 鈴木が桑の萎縮病について, 化学の面か ら一つの体系化を行なったことは高く評価されてよい.

戦前, 戦中に特いて, わが国でなされた世界に誇る二 つの有名な植物病理化学的研究がある. 一つは, 藪田貞 治郎, 住木諭介らによってなされたイネ馬鹿苗病の研究 であり，他は樋浦誠によって行なわれたサッマイモ黒斑 病の研究である. 前者の研究としては, イネが馬鹿苗 病菌に沶かされると徒長する因子として，ジベレリン （gibberellin）を単離，結晶化したことである，彼らは， その化学的研究を発展させるばかりでなく, それを徒長 “ホルモン”として一種のホルモンとみなし, その応用 研究にも力をそそいだ(3). 現在では，この種の類似化合 物が数十種も単離, 同定され, しか子植物の生長, 分化 を制御する正真正銘のホルモンであることがわかってい る.

後者の研究としては, サッマイモが黒斑病菌に拉かさ
れると生産する苦味物質, イポメアマロン (ipomeamarone）を単離し，それがセスキテルペンであることを指 摘したことである。しかも，本成分が本菌の胞子発芽を 抑制することより，防御因子として働くことを示唆した ことである(4). 現在では, 多くの植物が病菌の侵入を受 けると抗菌性物質を生産し，それが防御反応に関与する とみなされ，一般にこの種の物質をファイトアレキシン (phytoalexin) と称している(5,23).

この種の研究に刺激を受けながら，わが国に特ける植 物病理化学は, 戦後とくに発展した動的生化学と天然物 化学の考え方手法をとり入れつつ, 主に農芸化学と植 物病理学の両分野に括いて発展した.

\section{1. 生物化学の二つの流れ}

20 世紀当初から今日まで, 生物化学には二つの大きな 流れがあった. 一つはより化学的立場に立つもので, 無 細胞系で取り扱いらる生命現象を化学的に解析すること に主眼を和いた。他はより生物学的立場からのアプロー チであり，細胞系で示される生命現象を化学的に分析す ることに中心を执いた，いずれの立場をとるにしろ，と の研究課題は時代とともに変遷しまた二つの立場から 得られた研究方法や成果は相互に利用されている.

前者における研究課題の移り変りをあげてみると，た とえば，生体成分の分離・性質—必須微量成分（生理

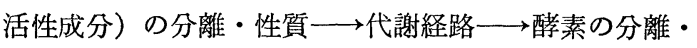
性質 $\longrightarrow$ 蛋白質・核酸の生合成 $\longrightarrow$ 酵素生成の制御 $\longrightarrow$ 酵素活性の制御—細胞内小器官の形成—膜の構造と 機能, として示される，一方，後者に信りるその移り変 りを眺めると, 生物学的エネルギー論 一細胞調節— 増殖・遺伝 $\longrightarrow$ 形質発現 $\longrightarrow$ 多細胞の形成・分化・相互 調節 (がん, 細胞免疫をふくめ) 一刺激伝達 (脳・神経 
を含め)，のように指摘される。

植物病理化学の場合, 植物と傷害因子（多くはカビの ような寄生者）との相互作用によりひき特こされる生命 現象を化学の言葉で説明する以上, 後者の立場にたつこ ととなろち。

\section{2. 植物病理化学の二つの方向}

植物はヒトや動物と同じように多くの病気をもってい る、たとえば, カビ, パクテリア，マイコプラズマ拉よ びウイルスによる感染病, 害虫による寄生病, 風雨や動 物食害による機械的傷害, 空気, 土壌など環境中の污染 物や農薬による傷害（いやち現象も含め ${ }^{(6)}$ ), 不可欠元 素の欠乏または過剩による栄養障害, 冷害または熱害, 旱䰠や堪水に伴う生理障害, さらには遺伝的疾患も含ま れる.

植物は, 発芽より種実形成の過程で, 古い葉の落葉や 果実の追熟，さらには一個体の枯死のように，老化現象 を示す.これは, 植物の生活環のらちに拈ける自然現象 の一つではあるが，乙かし，健康な状態を失うといら意 味で, 植物にとっての異常現象である.

さて, これらの感染病, 生理病, あるいは老化といっ た異常現象を化学的に解析することは, 傷害因子に対す る植物の防御機構，または傷害因子による病徵拡大の機 構を解明し, 病害防除の方法を指摘する道に通じる.こ れは植物病理化学の正統な方向である(7).

他の方向としては，植物一傷害因子相互作用に㧤いて， 植物や寄生者が示す異常現象の化学的実態を解明し，そ れを意識的に, 基礎および応用の他分野に役立たせるこ とがあげられる(8). 異常現象は, 本来生物がもつ生物学 的法則を顕した結果とみることができ，それだけに，植 物生理学や微生物生理学, また農芸化学のらちの他の関 連領域の発展に奇与することとなろう.

後者の方向が発展してきたのは, 前者の立場に立った 植物病理化学が, 抵抗性や罹病性を追求する間に積み上 げられてきた知識, さらには生物観に負らところが大き い. しかし, 植物病理現象の化学的内容を追求すればす るほど，そこにかくされた謎にひかれてますますその深 みに入ってゆくが自然である.このことは，どの分野に 拉いても, 自己の専門とする分野を何よりも深く掘り下 げてゆこうとすることからも理解される.したがって， 後者の方向は, もともと他のキャリアーをもつ人が植物

Vol. 12 , No. 8
病理化学に進んできた場合によくみられるようである. 先にあげたイネ馬鹿苗病の化学的研究から発展したジべ レリン学 ${ }^{(3)}$ は, その適切な例である.

前者が “異常をみつめる”立場であるとすれば，後者 は, “異常から正常をみつめる”立場である.

\section{3. “異常をみつめる”}

高等植物は, 動物と同様に単細胞生物から進化した多 細胞生物である，したがって，高等植物のらちには，単 細胞生物や動物に共通した代謝経路や細胞調節機構が存 在する. 一方，植物と動物とはとの進化の道すじが異な っているが，どちらも多細胞系として発展してきたため に，多細胞生物としての共通の法則性が認められる。 そ れは, 分化によって生じた各種の器官の分業と相互調整 である。

動物と異なる植物の特徴としては, 循環系統, 神経系 統および運動機能をもたず，一箇所に固着したままで経 時的に発育，分化し，その一世代を経過することである したがって，植物は進化の過程で，外部要因に依存して 成育する形質を身につけた。 このことは，たと竞ば春化 作用や光周性からも理解される．植物はまた環境に適応 するとともに，それぞれの環境因子のある範囲内の変化 に対応しうる形で成育する，あるいは思わぬ外敵（各種 の病原体や食害する動物）に拮抗しつつ一世代を終え る.

異常現象は,その植物にとって適当ではない外部要因 に沶かれた場合に現われる。一箇所に固着して成育する ためにも，自給栄養的性質が保持されてきた，大気中に ほぼ一定量存在する酸素や炭酸ガスは別にして，土壤中 の栄養物質はその一世代を通じて常に適量に存在するわ けではない，植物は栄養物質の過剩や久乏の状態に特い ても，それらの変化に対応して成育を進める調節機能を 獲得している. NやKが不足すると，下葉は黄化し，や がて枯死するが，これは下葉を犠牲にして上葉や頭頂部 の成育を保持する術であろう。

そのほかの環境因子も，植物にとってその毎日毎日が 必ずしも好ましい状態にあるわけではない，激しい雨や 風に当ってもそれから逃れることができない，そのため に茥や根を堅牢な外壁によって保護している，それでも 不幸にして機械的傷害を受けることがある．その時に， 傷害を受けた細胞や隣接の細胞はその傷害を認識し，傷 
害からの修復を始める。乙かし, その一連の過程は異常 現象として観察される。

温度, 日照, 土壌水分なども, 必ずしも常に適当の值 にあるわけではない、その起源が熱帯地域である植物は 暑さには強いが寒さには弱い。サッマイモやバナナなど はある低温 $\left(10^{\circ}\right.$ 前後) までは耐えられるが, それより低 い温度に数日間呿かれると生理的変調に括ちいる。

自然条件下で, 植物はその一生のらちに何回となくカ ビ，バクテリア，ウイルスなどの攻撃を受ける．しかし， 多くの場合に, 進化の過程で獲得した防御機構によって, その侵入は最少限に抑兄られる. 時にはそれに抗しきれ ず,一方的に侵されることもある，それに打ち勝つかあ るいは敗れるかは, 植物と寄生者の遺伝的形質とともに, 植物一寄生者複合系が和かれる環境因子によっても左右 される.

以下に，主に感染病に括ける最近の課題に中心を括き ながら，推定を交えつつ“異常をみつめる”ことにした W.

\section{1）植物の異物認識}

植物は気孔や傷害部から病菌の侵入を受けると, それ を異物として認識する. その認識には二つの方法がある. 一つは植物中にその異物に対応するレセプターが存在す る場合で，異物ーレセプター結合によって何らかの細胞 傷害がひき起こされることとなろら．他はとの異物によ って細胞傷害を受ける場合で，心ずしも病菌侵入とは限 らず，切断のような機械的傷害によっても，有毒な化学 試薬処理によってもみられる.

まず，前者について述べたい，植物の原形質構成高分 子中のある種のものは, 侵入する病菌の高分子と相互作 用を行ない，病菌を異物として認識することとなろう. この両者の高分子（多分蛋白質）は，それぞれ原形質膜 上にある可能性がある. 両者の結合は植物細胞にも病菌 細胞にも傷害を与光，それが刺激となって一連の代謝变 動を誘導することが考えられる. これによって, 強抵抗 性にみられる, 病菌侵入に伴ら植物細胞の速やかな細胞 褐変死一一過敏感反応一が説明されるかもしれない(9). また，植物側の高分子として，レクチン(赤血球凝集素) ないし関連化合物が関与することもあろら ${ }^{(10)}$.

次に後者について考えよう. 病菌がいったん植物細胞 内に侵入すると，前述のレセプターとの特異的結合によ らずとも，物理的に，あるいは病菌が分泌する酵素や毒
素の化学的作用により, 植物細胞の原形質膜は非特異的 に傷つけられ，植物は傷害により病菌を認識する.

\section{2) 植物の傷害に伴う反応}

植物は単なる切断傷害によっても激しい細胞の变化を 示す. この変化は一般に病菌侵入によってもみられ，そ の程度はさらに大きい. しかし, 切断傷害に伴ら変化が かえって抑えられることもあれば，切断傷害ではみられ ない病菌侵入に固有の反応がみられることもある.ここ では, 切断傷害によって起こる変化について蛋べたい.

i ）傷害呼吸： 植物組織が傷害を受けると, 数時間 の lag 期ののちに急速に呼吸が上昇し， 1 日目で約 2 倍 に達する。これを傷害呼吸(wound respiration) と呼ぶ。 これは，核酸の合成や蛋白質（各種の酵素）の合成の反 映であり, 多量の ATP の利用の結果でもある. 一方, 呼吸の担い手であるミトコンドリア $(\mathrm{Mt})$ の形成 ${ }^{(11)}$ や糖 代謝に関与する酵素群 (たとえばグルコース 6-りん酸デ ヒドロゲナーゼや酸性インベルターゼ)の合成 ${ }^{(12)}$ が起こ り，呼吸の代謝経路のパイプを大きくすることにもよる.

ii）ポリフェノール生成： ポリフェノールの生成も また，傷害を受けた組織に共通してみられる，その主成 分はクロロゲン酸のようなフェニルプロパノイドである. この生成に先立って, この生成経路中のいくつかの酵素 が合成される、たと学ば，フェニルアラニン（Phe）を 脱アミノしてトランス $(t)$-桂皮酸にする Phe アンモニ アーリアーゼや， $t$-桂皮酸を 4 -ヒドロキシ桂皮酸にする $t$-桂皮酸 4 -ヒドロキシラーゼがこれに当る(13)。 これら の酵素は, ポリフェノール量が最大になる以前に不活性 化されてゆく. 前者は可溶性画分に, 後者はミクロジー 么画分に存在するが, その合成, 不活性化の挙動は酷似 している. これらの酵紊より扰くれて, ポリフェノール オキシダーゼがアイソザイムとして合成されてくるのも， 傷害に伴う一般的な像である(14).

iii）癒傷層の形成：傷害を受けると,やがてリグニ ン層, コルク層またはカルス層が形成され，その傷を瘉 す. それに先立ちペルオキシダーゼの各種のアイソザイ ムが合成されるが，リグニンの形成には，表層部位にの み合成されるある特定のアイソザイムが関与するらしい。

\section{3）植物の感染に伴う反応}

病菌侵入は連続的刺激を植物に与え, 植物は切断傷害 に伴ら諸変化の注かに特有の反応を示す。また，侵入の ある限り，リグニンの形成は抑制されることがある。 
i ）異常呼吸増加： 感染 1 日目では, 傷害呼吸之ほ ぼ同じパターンの呼吸増加がみられる。病菌の侵入がな 物も続くと，短期間の間を特いて再び呼吸が増加する。 その時に Mt の活性は増加するが， その数は増加しない。

ii）エチレン生成：植物が感染を受けると，切断傷 害とは比べるのにならないほど多量のエチレンが，十数 時間の lag 期を経て生成される(15). その生成経路は切 断傷害の場合とは異なり，TCA サイクルを含む経路と ともに，非代謝性の細胞内成分を出発物とする経路が関 与する．被害部を除いた隣接健全組織だけでは，その生 成は止まってしまう。すなわち，先の生成には，病菌の 宿主内活動が不可欠である.

iii）.クマリン生成：切断傷害の場合にはみられない のに, 病菌の侵入を受けると, 被害部ないしごく隣接の 健全組織にクマリン類が集積される。本成分は抗菌性を 有することから，次のファイトアレキシン (Phy) の一 種とみなすこともでさようが，その生成が早期に起こる ことや生成様式から，一応別のものとして扱った。

iv）ファイトアレキシン生成： 前述のように, Phy に属する最初の成分として, 樋浦は黒斑病䍜病サッマイ モよりイポメアマッンを分離し(4)，のち久保田括よび松 浦によりその構造が決定された ${ }^{(16)}$ その後, これに関連 する数種の成分が分離された。また，疫病菌に侵された ジャガイモから，リシチン (rishitin) が分離, 同定さ れ(17), サッマイモの場合と同様にテルペン類であるこ とがわかった. 一方, 数種のまめ科植物から分離された ものは, ピサチン (pisatin) のよらにイソフラボノイド 誘導体である ${ }^{(5,24)}$. その他の植物からの本成分も含め, その構造から共通していえることは，その生合成にアセ チル CoA が関与するとみられることである.

その合成, 集積機構は, 罹病サッマイモの場合から次 のように考兄られる(18,19).

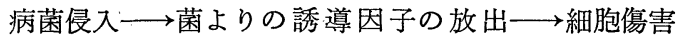
一植物への刺激伝達—DNA 鋳型のアンマスキング $\longrightarrow$ 酵素合成 $\longrightarrow$ Phy 生成系の完結 $\longrightarrow$ Phy 合成, 集積.

ここで, 病菌の誘導因子が直接植物染色体に働くのか, それとも宿主細胞に働いてあるホルモン様物質を放出さ せ，それが染色体に㗢くかは，今後の中心課題の一つで ある.Phyは単なる切断傷害では合成されないが，病菌 侵入のみでなく，昇录のような毒物処理によってもつく られる(8). v ）リグニン形成： 植物によっては, 病菌の侵入に 反応してりグニンを形成することがあり ${ }^{(20)}$ ，たとえばダ イコン, カボチャ, キウリなどにみられる. このリグニ ンは普格のリグニンよりも $p$-クマロイルアルコール骨 格をより多く含み，その生成機構はPhy 飞酷似する.

\section{4）防御反応}

侵入する病菌を認識し，植物細胞は過敏感反応により ネクロシスを起こす．この過程でポリフェノールはポリ フェノールオキシダーゼの作用により酸化, 重合され, 物理的バリアーが形成される，このバリアーの形成も含 めて，一次的防御反応が成立するとみられる．これに引 き続いて起こるPhy やリグニン形成が，二次的防御反 応に関係するのであろう.

防御反応は，植物の種と病菌の種の組合せ如何によっ て, 相当の幅がある. 防御反応の特異性は, 植物の異物 認識, 過敏感反応, Phy 生成能, また Phy の抗菌性な ぞの大小によってもきまるのであうう.

\section{5）䍙 病 性}

植物は進化の過程で, 防御反応に関連する遺伝的形質 を獲得した. しかし, 病菌のほうも突然変異を通じて, 抵抗性をもった植物種を再び侵すようになる。

i）誘導䍜病性：植物と病菌との間に親和性が保た れ, 過敏感反応を示さずに共生的となれば, 病菌の植物 内での成長が可能となるわけで, 植物は罹病的となる.

これは, 病菌の注うの積極的働きかけにより, 過敏感反 応やそれに続くPhy 生合成を抑制するためかもしれず， その際，誘導罹病性が成立するわけである，その成立の のちには, 次に不親和性の菌種を接種しです植物は過敏 感反応を示さない(17)．この物質的基礎はよくはわから ないが，そのような系には，植物と病菌との間に共通抗 原が存在することが見いだされている．また，コムギー コムギさび病菌系で見いだされているように，温度条件 を変えたり, エチレン処理の有無によって, 䍜病性-抵 抗性を変換できることがわかってきた.

ii）宿主特異性毒素：ある種の病気の進展が，その 寄生者が分泌する毒素とのものによってひき起こされる ことがあり，この種の毒素を宿主特異性毒素と呼ぶ(21). わが国では，ナシ黒斑病やリンゴ斑点落葉病が有名であ る. この場合，その植物の膜に毒素と特異的に結合する レセプターが存在すると考兄られる.

iii）非特異性毒素： 多くの病菌は, 植物に着生した 
のち, 植物に有毒ないろいろの化合物を分泌し, 病徵を 拡大させる. 䍜病性を一次的に決定するものではないの で, この種のものを非特異性毒素と呼ぶ. 初めにあげた ジベレリンもこれに属する.玉利らの研究によれば, イ モチ病菌は $\alpha$-ピコリン酸 $(\alpha$-picolic acid), ピリクラリ ソ (piricularin) 特よびテヌアゾン酸 (tenuazonic acid) を生産し, 病斑拡大に寄与する(22). 最近のわが国の研 究をあげれば, 赤クローバーの一病菌, Phyllostica sp. が分泌するフィロシノール (phyllosinol) とフィロスチ ン (phyllostine) があげられる(23). そのほかにも数多く の毒素が見いだされ，これらが生理活性能をもつので, わが国に括ける研究も数多くある(24).

iv）病原性酵素：病菌はその病徵拡大にあたって, 細胞壁や細胞膜を破壊する酵素を分泌する. その一例が 多犯性の白絹病菌が分泌するぺクチナーゼである ${ }^{(25)}$. 本菌は侵入時にシュウ酸をも分泌するが, 酸性側に至適 $\mathrm{pH}$ を持つ本酵素にとって都合がよい.

v）環境因子：環境因子もまた，罹病性に大きくか かわり合いをもつことがある. 前述のように, サッマイ モのような熱帯性植物は低温に感受性であり ${ }^{(26,27)}$, 低温 に数日間おくと,たと室温にもどしても生理的に劣化 してゆき，普通ならば侵されない軟腐病菌の攻撃を受け， その分泌するペクチナーゼにより軟腐病をこうむる.こ れは, 低温下ではタンパク質-脂質複合体である Mt 膜 やその他の生体膜の模造が破壊され, その機能を失うた めである.

\section{4. “異常から正常をみつめる”}

前章で，植物に括ける異常現象のあるトピックについ て，化学の立場から概観してみた. この化学的実態はま だまだ未知のままに残っており，それだけに，正常な現 象を扱ら植物生化学, 植物生理学などの関連分野の研究 成果や方法を，より一層応用することが不可欠である.

しかし一方, 異常現象の化学的内容が明らかになるに つれて, その解析の過程で, 常に正常をみつめる立場を とれば, 異常, 正常を問わず, 本来生物がもつ重要な数 数の生物学的法則を把握しうる鍵が見いだせる可能性の あることもわかってきたまなたそれによって新しい応 用分野も展開されるものと期待される.

\section{1）酵素, 細胞小器官の合成とその調節機作}

病・傷害に反応して, 植物は速やかに各種の酵素や細
胞小器官を合成し，その中のあるものはやがて不活性化 されてゆく，この解析は一般に，植物細胞が酵素合成や 細胞小器官形成にもつ調節機作の解明に通じる. とくに, それまで不活性の状態にあった DNA に鋳型活性が現わ れる引き金となる誘導物質の発見が期待される。これは， 植物の細胞分化の化学的基礎の解明にも通じる. この系 はまた, エチンンの生成と作用機構の解析に適切なもの である。

\section{2）新代謝成分の発見とその代謝経路}

現在，多くの植物よりいろいろの Phy が見いだされ ているが，それでも，現存の植物種のうちのほんの一部 しか試験されていない、今後の研究により, 新しい構造 と生理活性能をもった二次生産物の発見が期待され, そ れに関連してその代謝経路も解明されるであろう.

\section{3）刺激伝達之物翼移行}

病・傷害に伴い形成ないし放出される刺激(誘導物質) の実態と, 刺激伝達の仕方を解析し, 一方, 組織の内方 にあるいろいろの中間体が病・傷害部に移行する機構を 明らかにすれば，それはそのまま細胞間相互調整の一般 像を解明することとなろう.

\section{4）種間の遺伝的類緑関係}

病・傷害に伴い生成される二次生産物や，その合成の ために前もって形成される酵素は, 種間の近縁関係, し たがって系統発生の相関性を解析する上で有力な方法を 提供することとなる ${ }^{(8)}$.

\section{5）瘾傷組織, 腫瘍組織の形成}

病・傷害に反応して、リグニン層, コルク層, または カルス層が形成されたり,さらに腫瘍が形成されること がしばしばある．これらは，細胞増殖の機作と，それに 関与するホルモン類の性質と役割を解明する上に役立つ.

\section{6）異種細胞間の相関性}

植物-寄生者相関性にみられる親和性, 不親和性の解 析は, 接木, 授精, 種間交雑, 分化細胞間調節, また異 種遺伝子導入のような関連課題に重要な示唆を与えるで あろう。

長い歴史の過程で, 微生物, 植物, 動物は相互に協調 し，あるいは相古しつつ現在のような生態系を創り上げ た. 植物-寄生者の間にみられる細胞や代謝の変動, さ らには Phy の生成を解明することは, この生態系の維 持の機構と今後の発展方向について, 何らかの寄与をな しらるかもしれない,さらにまた, この種の研究は, 公 
害污染源の植物個体や植物群に及ぼす影響を研究する上 の基礎として役に立ち, 化学生態学の面にも寄与するこ とになろう.

\section{7）生理病, 遺伝病の活用}

熱帯性起源の植物は低温に弱く, 反対に寒冷地域の植 物は高温に弱い，そのほか不適当な栄養, 光, あるいは 水分のるとでも生理病をひき起こす. 自然条件のもとや $\gamma$-線照射などの人工的処理のもとで，いろいろの変異植 物が出現し，遺伝病を形成する。これらの活用もまた細 胞の機能と形態を分析するのに役に立つ.

植物の生命現象の解明に, 異常からみつめることが案 外に有効なアプローチであることを強調した. しかし， すでに多くの研究者が多少ともその方向で研究を進めて いる. 動物についてはがんに関連して，微生物について はウイルス病に関連して，こうした方向の研究が活発に 行なわれているだけに，この方面の研究史を調べること は有効である。

農芸化学分野には, 植物化学, 植物生化学の領域で活 躍している研究者は数多く括り, 彼らが農芸化学以外の 他の農学分野や, 理学, 薬学分野の研究者とともにわが 国の植物科学の主として化学的側面の研究に寄与してい る. 今後, 植物科学は, 食糧, 環境問題も加わって, さ らに複雑な生命現象を化学の言葉で説明する力向に一層 発展すると思われる. この際, 植物病理現象も含め, 高 次の生命現象に属する課題に立ち向からことが望まれて よいと思う. そのためには, 化学と生物学に属する広い 領域への関心と理解を基礎にして，初めて実を結ぶこと となろう.

“異常から正常をみつめる”ことに中心を括いて話を すすめたが, “異常をみつめる”こともまた，農芸化学 者が自らの研究課題として選んでよいと思う. 長い進化 の過程で保持するにいたった防御反応, 癒傷反応, 不良 環境への適応反応こそ, 植物の最も基本的生命現象の一 つとみなされるからである。

\section{文献}

1）鈴木梅太郎博士顕彰会，鈴木梅太郎先生伝刊行会：“鈴木 梅太郎先生伝”，朝倉書店，1967， p. 354 .

2）土居養二：化学と生物, 7, 260 (1969).

3）住木諭介：“植物ホルモン”, 河出書房, 1951, p. 545.

4) 桶浦 誠: 化学と生物, 6, 428, 492 (1968).

5) 植原一雄：化学と生物, 6, 726 (1968).
6）滝島康夫 : 化学と生物，3，530 (1965).

7）平井篤造, 鈴木直治編：“感染の生化学一植物”, 農業技 術協会, 1970, p. 473 .

8）瓜谷郁三：化学と生物, 4, 647 (1966).

9）富山宏平，李好植，道家紀志：日植病報，40，70(1974).

10) M. Kojima \& I. Uritani : Plant \& Cell Physiol., 15, No. 4 (1974).

11）旭 正: 化学と生物, 4, 299 (1966).

12）松下一信: 化学々生物, 12, 314 (1974).

13）南川降雄 : 化学と生物, 5, 310 (1967).

14）兵藤 宏: 化学々生物, 5, 441 (1967).

15）今関英雅 : 化学々生物, 6, 340 (1968).

16) T. Kubota: "Cyclopentanoid Terpene Derivatives", ed. W.I. Taylor \& A.R. Battersby, Marcel Dekker, New York, 1964, p. 312.

17）富山宏平 : “坂本正幸教授還暦記念論文集”, 1968, p, 141; 日植病夏の学校講演集, 97 (1973).

18）大羽和子：化学と生物, 6, 767 (1968).

19）小国伊太郎：化学と生物, 7, 408 (1969).

20）浅田泰次：農業及園芸, 45，1035 (1970).

21）西村正暘：化学々生物，3，490 (1965).

22) 玉利勤治郎：化学々生物, 4, 67 (1966).

23) 酒井隆太郎, 坂村貞雄: 化学々生物, 8, 189 (1970).

24）高橋信孝, 丸茂晋吾, 大岳 望: “生理活性天然物化学”, 東京大学出版会, 1973, p.348.

25) 梶 明: 化学と生物, 11, 330 (1973).

26）邨田卓夫：化学と生物，9，370 (1971).

27）山木昭平: 化学と生物, 11, 760 (1972).

\section{定価値上げについてのお願い}

日ごろは「化学と生物」誌をご愛読いただき まして，厚く御礼申し上げます。

扮かげ様にて順調に発行を続けてまいりまし たが，昨年来の物価の異常な高騰により，本誌 も多大の影響を被り，再度，定価の值上げをせ ざるをえなくなりました。

さきに，本年 4 月より 330 円（18\%増）飞定 価を改めさせていただき，何とかしてこの線を 維持しようと努力いたして怙りますが，その後 も経費は 30\% をはるかにこえて増大をつづけ て拉り，ついに抗しきれなくなった次第でござ います.

まことに心苦しいことではございますが，来 る 9 月号より 380 円に值上げさせていただきた くななとぞ現状を御理解くださいますよう特 願い申し上げます。

今後とも, 内容の充実に一層心を尽す所存で ございますので，ひきつづき愛読くださいます よう，あわせて报願い申し上げます。

\section{財団法人 東京大学出版会}

